Supporting Information

Bottlebrush Polymers Based on RAFT and "C1" Polymerization

Method: Controlled Synthesis and Application in Anticancer Drug

\title{
Delivery
}

Meng-Qing Wang, ${ }^{1, \dagger}$ Hui Zou,,${ }^{1, \dagger}$ Wen-Bin Liu, ${ }^{1} \mathrm{Na}$ Liu,,${ }^{1, *}$ and Zong-Quan $\mathrm{Wu}^{1,2, *}$

${ }^{1}$ Department of Polymer Science and Engineering, School of Chemistry and Chemical

Engineering, and Anhui Key Laboratory of Advanced Functional Materials and Devices, Hefei University of Technology, Hefei, Anhui Province 230009, China.

${ }^{2}$ State Key Laboratory of Supramolecular Structure and Materials, College of Chemistry, Jilin University, Changchun 130012, China.

$\dagger$ M.-Q. Wang and H. Zou contributed equally to this work.

*To whom should be addressed:

E-mail: zqwu@jlu.edu.cn (Z.W.) or zqwu@hfut.edu.cn (Z.W.)

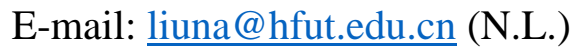


Synthetic procedures S4-S11

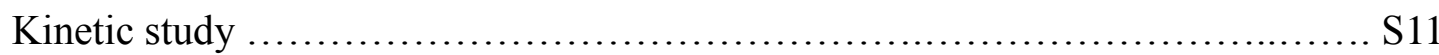

AFM measurements ...................................................... S12

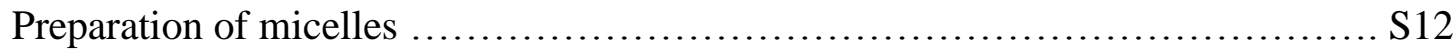

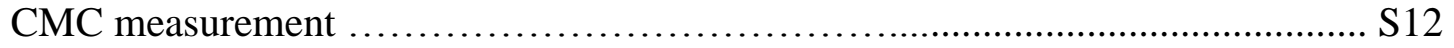

Preparation of NR- and DOX-loading micelles ............................... S13

In vitro DOX release profile and cytotoxicity investigation ................ S13-S14

Table S1. Characterization Data for the Macro-CTA ............................ S15

Table S2. Characterization Data for the Bottlebrush Polymers .................... S15

Table S3. Characterization Data for $\left(1-\mathrm{PS}_{30}\right)_{50}-b-(2-\mathrm{PEG})_{100} \ldots \ldots \ldots \ldots \ldots \ldots \ldots \ldots . \mathrm{S} 15$

Figure S1-S5. ${ }^{1} \mathrm{H},{ }^{13} \mathrm{C}$ NMR and FT-IR, and spectra of $\mathbf{1}$ and 3 .............. S16-S18

Figure S6. Kinetic studies for the macromonomer polymerization ................. S18

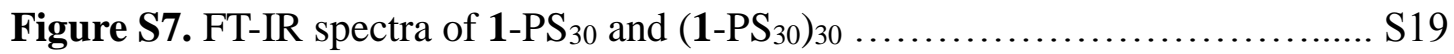

Figure S8. AFM height images of bottlebrush polymers ....................... S19

Figure S9. ${ }^{1} \mathrm{H}$ NMR of 2-PEG........................................ S20

Figure S10. FT-IR spectra of 2-PEG and (1-PS 30$)_{50}-b-(2-P E G)_{100} \ldots \ldots \ldots \ldots \ldots . . . . . . .220$

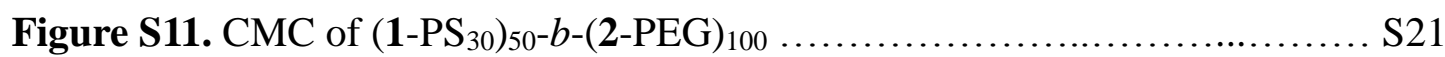

Figure S12. Fluorescent spectra of pyrene and polymer mixtures .............. S21

Figure S13. Fluorescent changes NR@(1-PS $\left.)_{30}\right)_{50}-b-(2-\mathrm{PEG})_{100} \ldots \ldots \ldots \ldots \ldots \ldots . . . . . . . . . .21$

Figure S14. Fluorescent spectra of polymer with and without DOX loading ...... S22

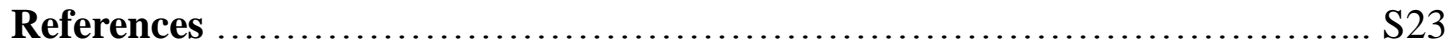




\section{General considerations}

Size exclusion chromatography (SEC) was performed on Waters 1515 pump and Waters 2414 differential refractive index (RI) detector (set at $40{ }^{\circ} \mathrm{C}$ ) using a series of two linear TSK gel GMHHR-H columns. Molecular weight $\left(M_{\mathrm{n}}\right)$ and its polydispersity $\left(M_{\mathrm{w}} / M_{\mathrm{n}}\right)$ data were reported relative to polystyrene standards. The eluent was tetrahydrofuran (THF) at a flow rate of $0.8 \mathrm{~mL} / \mathrm{min}$. The nuclear magnetic resonance (NMR) spectra were recorded using a Bruker 400 and $600 \mathrm{MHz}\{\mathrm{H}\}$ spectrometer operated in the Fourier Transform mode. Chemical shifts are reported in delta $(\delta)$ units and expressed in parts per million (ppm) downfield from tetramethylsilane (TMS) using the residual proton solvent as an internal standard. FT-IR spectra were recorded on Perkin-Elmer Spectrum BX FT-IR system using $\mathrm{KBr}$ pellets at $25{ }^{\circ} \mathrm{C}$. The UV-vis absorption spectra were recorded on a UNICO 4802 UV/vis double beam spectrophotometer. Fluorescence spectra were recorded using a Hitachi F-4600 fluorescence spectrophotometer. Atomic force microscope (AFM) was performed on a Cypher S microscope (Oxford Instruments, Asylum Research).

All solvents were obtained from Sinopharm. Co. Ltd., and were purified by the standard procedures before use. All chemicals including ( $\pi$-allyl) $\mathrm{PdCl}$ were purchased from Aladdin, Sinopharm, and Sigma-Aldrich Chemical Co. Ltd., and were used as received without further purification otherwise denoted. The phosphine ligand $\mathrm{L}$ was prepared according to reported literatures with slight modifications, and the structure was confirmed by ${ }^{1} \mathrm{H}$ NMR. ${ }^{1-4}$ The monomer was prepared followed the Scheme S1. 


\section{Synthetic procedures}

\section{Scheme S1. Synthesis of RAFT agent.}

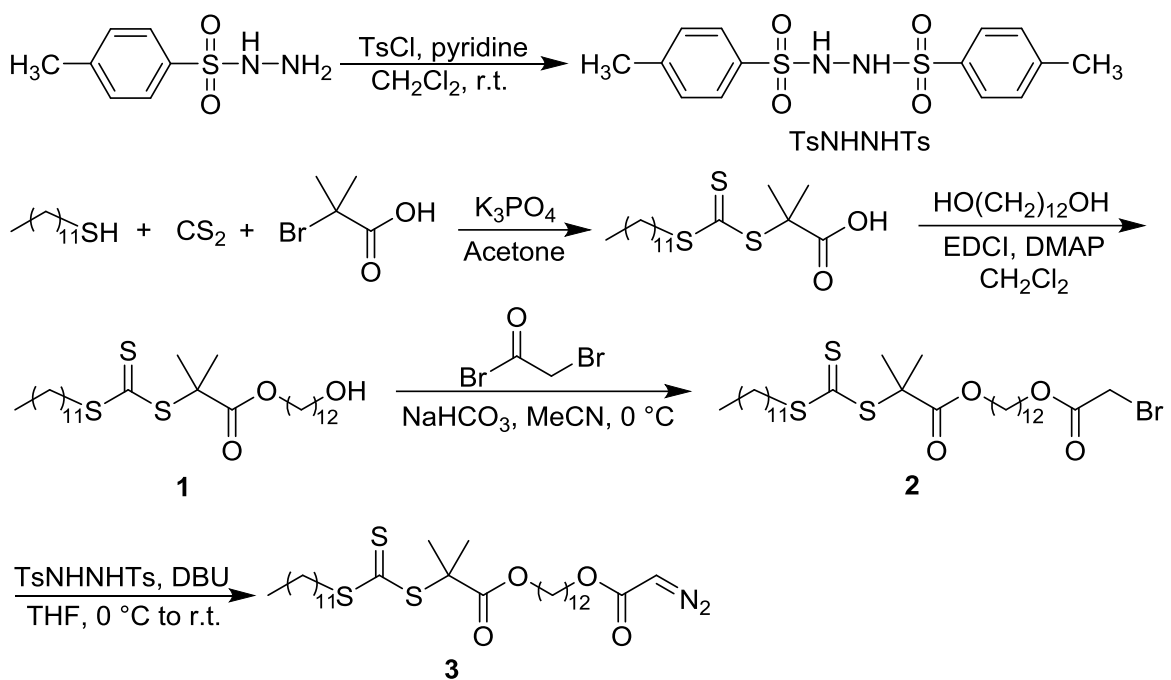

Synthesis of TsNHNHTs. ${ }^{2}$ A flame-dried, $500 \mathrm{~mL}$ round-bottomed flask fitted with a magnetic stir bar was charged with $p$-toluenesulfonyl hydrazide (18.64 g, 0.10 mol) and $p$-toluenesulfonyl chloride $(28.60 \mathrm{~g}, 0.15 \mathrm{~mol})$ in anhydrous $\mathrm{CH}_{2} \mathrm{Cl}_{2}(100 \mathrm{~mL})$. The mixed suspension was stirred at room temperature while pyridine $(12 \mathrm{~mL}, 0.15$ mol) was added dropwise over $1 \mathrm{~min}$. During the addition, the reaction mixture became homogenous and turned yellow. White precipitate was observed within 3 min and the reaction mixture was stirred for further 90 min. Diethyl ether $(400 \mathrm{~mL})$ and $\mathrm{H}_{2} \mathrm{O}(200$ $\mathrm{mL}$ ) were added and stirred at $0{ }^{\circ} \mathrm{C}$ for $15 \mathrm{~min}$. The white solid which precipitates was collected in a Büchner funnel using suction filtration and washed with diethyl ether (100 mL). The solid thus obtained was dissolved in boiling methanol (400 mL). After cooling to the room temperature, precipitate appeared. About $200 \mathrm{~mL}$ of methanol was removed by rotary evaporation and cooled to $0{ }^{\circ} \mathrm{C}$. The precipitate was collected in a Büchner funnel using suction filtration and washed with cold methanol $(20 \mathrm{~mL})$ and 
diethyl ether $(100 \mathrm{~mL})$ to give $N, N^{\prime}$-ditosylhydrazine (TsNHNHTs) as a white solid $(29.01 \mathrm{~g}, 84 \%)$.

Synthesis of compound $1 .^{1}$ A flame-dried, $500 \mathrm{~mL}$ round-bottomed flask fitted with a magnetic stir bar was charged with $\mathrm{K}_{3} \mathrm{PO}_{4}(20.97 \mathrm{~g}$, $0.10 \mathrm{~mol})$ in acetone (80 $\mathrm{mL}$ ) and stirred for $10 \mathrm{~min}$. Then 1-dodecanethiol (20.00 g, $0.10 \mathrm{~mol}), \mathrm{CS}_{2}(22.57 \mathrm{~g}$, $0.30 \mathrm{~mol})$, and 2-bromo-2-methylpropionic acid (14.03 g, $0.08 \mathrm{~mol})$ was added sequentially, and stirred at intervals of ten minutes. The reaction mixture was stirred at room temperature for 12 hours. After the addition of $\mathrm{HCl}$ solution, the mixture was extracted with $\mathrm{CH}_{2} \mathrm{Cl}_{2}$, and the organic phase was dried over $\mathrm{Na}_{2} \mathrm{SO}_{4}$. After the removal of the solvent under reduced pressure, the residue was dissolved with $n$-hexane at $65^{\circ} \mathrm{C}$. Yellow solid (18.67 g, 75\%) was precipitated out after freezing, and the residue was used in the next step. The obtained residue (7.15 g, $19.61 \mathrm{mmol})$, 1-Ethyl-3(3dimethylpropylamine) carbodiimide (EDCI, 4.51 g, $23.53 \mathrm{mmol}$ ), and 4dimethylaminopyridine (DMAP, $1.92 \mathrm{~g}, 15.72 \mathrm{mmol}$ ) was dissolved in $\mathrm{CH}_{2} \mathrm{Cl}_{2}$ (100 $\mathrm{mL}$ ) and 1,12-dodecanediol (5.95 g, $29.41 \mathrm{mmol})$ was dissolved in THF (50 mL). The resulting mixture was stirred for $8 \mathrm{~h}$ at room temperature. After the addition of $\mathrm{H}_{2} \mathrm{O}$, the mixture was extracted with $\mathrm{CH}_{2} \mathrm{Cl}_{2}$, and the organic phase was washed by saturated $\mathrm{Na}_{2} \mathrm{CO}_{3}$ solution $(50 \mathrm{~mL}$, three times) and saturated $\mathrm{NaCl}$ solution $(50 \mathrm{~mL}$, three times). Then the organic phase was dried over $\mathrm{Na}_{2} \mathrm{SO}_{4}$, and the solvent was removed under reduced pressure. This material was further purified by silica gel column chromatography (ethyl acetate/petroleum ether), afforded compound $\mathbf{1}$ as a yellow solid (6.43 g, 79\% yield). ${ }^{1} \mathrm{H}$ NMR (600 MHz, $\left.\mathrm{CDCl}_{3}, 25^{\circ} \mathrm{C}\right): \delta 4.08-4.06(\mathrm{t}, J=6 \mathrm{~Hz}, 2 \mathrm{H}$, 
$\mathrm{CO}_{2} \mathrm{CH}_{2}$ ), 3.64-3.62 (t, $\left.J=6 \mathrm{~Hz}, 2 \mathrm{H}, \mathrm{CH}_{2} \mathrm{OH}\right), 3.27-3.25\left(\mathrm{t}, J=6 \mathrm{~Hz}, 2 \mathrm{H}, \mathrm{CH}_{2} \mathrm{~S}\right)$, 1.79-1.25 (m, 46H, $\mathrm{CH}_{2}$ and $\left.\mathrm{CH}_{3}\right), 0.88-0.86\left(\mathrm{t}, J=6 \mathrm{~Hz}, 3 \mathrm{H}, \mathrm{CH}_{2} \mathrm{CH}_{3}\right) .{ }^{13} \mathrm{C} \mathrm{NMR}$ $\left(150 \mathrm{MHz}, \mathrm{CDCl}_{3}\right): \delta 221.14,172.88,66.00,62.81,55.85,36.71,32.68,31.80,31.47$, $29.52,29.51,29.46,29.45,29.42,29.35,29.34,29.23,29.09,29.00,28.83,28.24,27.79$, 26.79, 25.80, 25.66, 25.25, 25.25, 22.57, 14.00. FT-IR (KBr, $\left.25^{\circ} \mathrm{C}\right): 2962\left(v_{\mathrm{C}-\mathrm{H}}\right), 2923$ $\left(v_{\mathrm{C}-\mathrm{H}}\right), 2856\left(v_{\mathrm{C}-\mathrm{H}}\right), 1643\left(v_{\mathrm{C}=\mathrm{O}}\right) \mathrm{cm}^{-1} . \mathrm{MS} \mathrm{m} / z$ calcd for $\mathrm{C}_{29} \mathrm{H}_{57} \mathrm{O}_{3} \mathrm{~S}_{3}[\mathrm{M}+\mathrm{H}]^{+}:$549.34; Found: 549.28. Anal. Calcd (\%) for $\mathrm{C}_{29} \mathrm{H}_{56} \mathrm{O}_{3} \mathrm{~S}_{3}$ : C, 63.45; H, 10.28; S, 17.52; Found (\%): C, 63.24; H, 9.34; S, 16.69.

Synthesis of compound 3. The compound 3 was prepared following the reported literatures with slight modifications. ${ }^{3}$ Under the $\mathrm{N}_{2}$ atmosphere, bromoacetyl bromide ( $0.80 \mathrm{~mL}, 9.16 \mathrm{mmol})$ was added dropwise to a stirred suspension of compound $\mathbf{1}$ (3.87 $\mathrm{g}, 7.05 \mathrm{mmol})$ and $\mathrm{NaHCO}_{3}(1.78 \mathrm{~g}, 21.15 \mathrm{mmol})$ in acetonitrile $(100 \mathrm{~mL})$ at $0{ }^{\circ} \mathrm{C}$. The resulting mixture was stirred for $30 \mathrm{~min}$ at this temperature. After the addition of $\mathrm{H}_{2} \mathrm{O}$, the mixture was extracted with $\mathrm{CH}_{2} \mathrm{Cl}_{2}$, and the organic phase was dried over $\mathrm{Na}_{2} \mathrm{SO}_{4}$. After the removal of the solvent under reduced pressure, the compound $\mathbf{2}$ was used in the next step without further purification. The obtained compound $\mathbf{2}$ and TsNHNHTs (2.64 g, $7.75 \mathrm{mmol})$ was dissolved in THF $(100 \mathrm{~mL})$ and cooled to $0{ }^{\circ} \mathrm{C}$. After 1,8 diazabicyclo [5.4.0]undec-7-ene (DBU, $3160 \mu \mathrm{L}, 21.15 \mathrm{mmol}$ ) was added dropwise to the mixture, it was stirred for $30 \mathrm{~min}$ at room temperature. After quenching of the reaction by the addition of saturated aqueous $\mathrm{NaHCO}_{3}$ solution, it was extracted with diethyl ether. The combined organic phase was then washed with brine, dried over $\mathrm{Na}_{2} \mathrm{SO}_{4}$, and evaporated to dryness to give a crude product as a yellow solid. This 
material was further purified by silica gel column chromatography (ethyl acetate/petroleum ether), afforded compound $\mathbf{3}$ as a yellow solid (2.89 g, 66\% yield). ${ }^{1} \mathrm{H}$ NMR $\left(600 \mathrm{MHz}, \mathrm{CDCl}_{3}, 25{ }^{\circ} \mathrm{C}\right): \delta 4.72\left(\mathrm{~s}, 1 \mathrm{H}, \mathrm{N}_{2} \mathrm{CH}\right), 4.16-4.14(\mathrm{t}, J=6 \mathrm{~Hz}, 2 \mathrm{H}$, $\left.\mathrm{CO}_{2} \mathrm{CH}_{2}\right), 4.09-4.07\left(\mathrm{t}, J=6 \mathrm{~Hz}, 2 \mathrm{H}, \mathrm{CO}_{2} \mathrm{CH}_{2}\right), 3.27-3.25\left(\mathrm{t}, J=6 \mathrm{~Hz}, 2 \mathrm{H}, \mathrm{CH}_{2} \mathrm{~S}\right)$, 1.69-1.25 (m, 46H, $\mathrm{CH}_{2}$ and $\left.\mathrm{CH}_{3}\right), 0.89-0.87\left(\mathrm{t}, J=6 \mathrm{~Hz}, 3 \mathrm{H}, \mathrm{CH}_{2} \mathrm{CH}_{3}\right) .{ }^{13} \mathrm{C} \mathrm{NMR}$ (150 MHz, $\left.\mathrm{CDCl}_{3}\right): \delta 221.29,172.97,109.96,66.09,64.99,55.96,46.08,36.81,31.87$, $29.59,29.58,29.52,29.51,29.50,29.49,29.47,29.41,29.30,29.20,29.17,29.07,28.90$, $28.75,28.32,27.85,25.88,25.78,25.35,22.65,14.08$. FT-IR $\left(\mathrm{KBr}, 25^{\circ} \mathrm{C}\right): 3108\left(v_{\mathrm{C}-}\right.$ H), $2930\left(v_{\mathrm{C}-\mathrm{H}}\right), 2863\left(v_{\mathrm{C}-\mathrm{H}}\right), 2112\left(v_{\mathrm{C}=\mathrm{N}_{2}}\right), 1727\left(v_{\mathrm{C}=\mathrm{O}}\right) \mathrm{cm}^{-1}$. MS m/z calcd for $\mathrm{C}_{31} \mathrm{H}_{56} \mathrm{~N}_{2} \mathrm{O}_{4} \mathrm{~S}_{3} \mathrm{Na}[\mathrm{M}+\mathrm{Na}]^{+}$: 639.34; Found: 639.34. Anal. Calcd (\%) for $\mathrm{C}_{31} \mathrm{H}_{56} \mathrm{~N}_{2} \mathrm{O}_{4} \mathrm{~S}_{3}$ : C, 60.35; H, 9.15; N, 4.54; S, 15.19; Found (\%): C, 60.32; H, 9.19; N, 4.50; S, 15.15.

\section{Scheme S2. Synthesis of PS macromonomer}

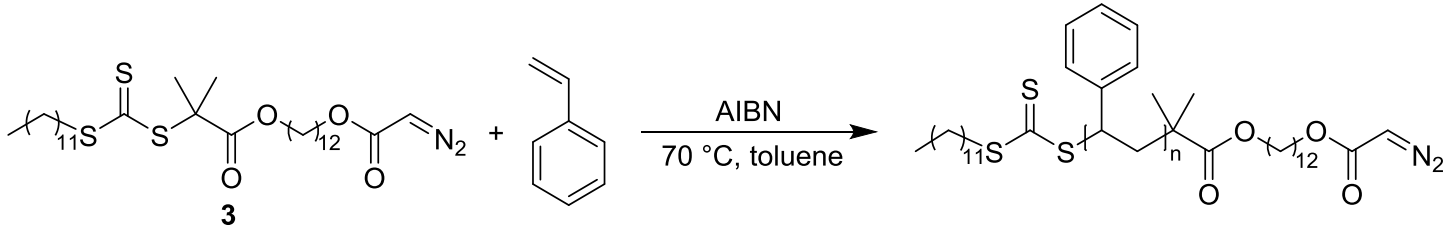

Synthesis of PS macromonomer. ${ }^{1}$ Taking the synthesis of 1-PS 30 as an example.

Under the $\mathrm{N}_{2}$ atmosphere, styrene (St, $4.05 \mathrm{~g}, 38.88 \mathrm{mmol}$ ), azodiisobutyronitrile (AIBN, $0.11 \mathrm{~g}, 0.67 \mathrm{mmol})$, and $3(0.80 \mathrm{~g}, 1.30 \mathrm{mmol})$ dissolved in toluene $(10 \mathrm{~mL})$ were weighed into a $100 \mathrm{~mL}$ Schlenk flask with a magnetic bar. After the flask content being degassed with $\mathrm{N}_{2}$ for 40 min, polymerization was run at $70{ }^{\circ} \mathrm{C}$ for $10 \mathrm{~h}$. After the polymerization solution was concentrated, it was precipitated into a large amount of 
cooling methanol. The yellow viscous polymer was obtained after freeze-drying (2.92 g, $72 \%$ yield $)$. SEC: $M_{\mathrm{n}}=2.8 \mathrm{kDa}, M_{\mathrm{w}} / M_{\mathrm{n}}=1.04 .{ }^{1} \mathrm{H} \mathrm{NMR}\left(600 \mathrm{MHz}, \mathrm{CDCl}_{3}, 25^{\circ} \mathrm{C}\right)$ : $\delta 7.37-6.32$ (brs, 5H, ArH of PS main chain ), 4.78-4.65 (br, 1H, $\left.\mathrm{N}_{2} \mathrm{CH}\right), 4.17-4.15$ (t, $J=6 \mathrm{~Hz}, 2 \mathrm{H}, \mathrm{OCH}_{2}$ of chain end segment), 4.11-4.09 (t, $J=6 \mathrm{~Hz}, 2 \mathrm{H}, \mathrm{OCH}_{2}$ of chain end segment), 3.84-3.75 (m, 1H, CH of PS main chain), 3.32-3.17 (m, 2H, $\mathrm{CH}_{2} \mathrm{~S}$ of chain end segment), 2.61-1.74 (m, $1 \mathrm{H}, \mathrm{CH}$ and $\mathrm{CH}_{2}$ of PS main chain), 2.02-1.74 (m, $2 \mathrm{H}, \mathrm{CH}_{2}$ of PS main chain), 1.65-1.15 (brs, $46 \mathrm{H}, \mathrm{CH}_{2}$ and $\mathrm{CH}_{3}$ of chain end segment), 0.90-0.87 (t, 3H, $\mathrm{CH}_{2} \mathrm{CH}_{3}$ of chain end segment). FT-IR ( $\left.\mathrm{KBr}, 25{ }^{\circ} \mathrm{C}\right): 3067\left(v_{\mathrm{Ar}-\mathrm{H}}\right)$, $3032\left(v_{\mathrm{Ar}-\mathrm{H}}\right), 2921\left(v_{\mathrm{C}-\mathrm{H}}\right), 2847\left(v_{\mathrm{C}-\mathrm{H}}\right), 2111\left(v_{\mathrm{C}=\mathrm{N}_{2}}\right), 1727\left(v_{\mathrm{C}=\mathrm{O}}\right) \mathrm{cm}^{-1}$.

\section{Scheme S3. Synthesis of PEG macromonomer}

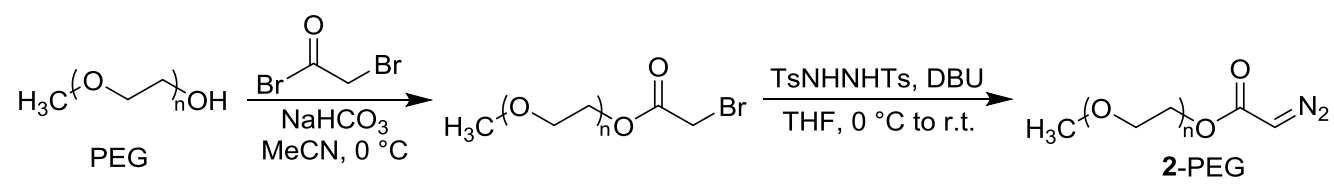

Synthesis of PEG macromonomer. This compound was prepared following the reported literatures with slight modifications. ${ }^{4}$ Under the $\mathrm{N}_{2}$ atmosphere, bromoacetyl bromide (330 $\mu \mathrm{L}, 3.77 \mathrm{mmol}$ ) was added dropwise to a stirred suspension of polyethylene glycol (PEG, $5.05 \mathrm{~g}, 2.52 \mathrm{mmol})$ and $\mathrm{NaHCO}_{3}(0.63 \mathrm{~g}, 7.50 \mathrm{mmol})$ in acetonitrile $(\mathrm{MeCN}, 100 \mathrm{~mL})$ at $0{ }^{\circ} \mathrm{C}$. The resulting mixture was stirred for $30 \mathrm{~min}$ at this temperature. After the addition of $\mathrm{H}_{2} \mathrm{O}$, the mixture was extracted with $\mathrm{CH}_{2} \mathrm{Cl}_{2}$, and the organic phase was dried over $\mathrm{Na}_{2} \mathrm{SO}_{4}$. After the removal of the solvent under reduced pressure, the residue was used in the next step without further purification. The 
obtained residue and TsNHNHTs (1.83 g, $5.38 \mathrm{mmol})$ was dissolved in THF (100 mL) and cooled to $0{ }^{\circ} \mathrm{C}$. After DBU ( $\left.2 \mathrm{~mL}, 13.40 \mathrm{mmol}\right)$ was added dropwise to the mixture, it was stirred for $30 \mathrm{~min}$ at room temperature. After quenching of the reaction by the addition of saturated aqueous $\mathrm{NaHCO}_{3}$ solution, it was extracted with diethyl ether. The combined organic phase was then washed with brine, dried over $\mathrm{Na}_{2} \mathrm{SO}_{4}$, and evaporated to dryness to give a crude product as a yellow solid. This material was purified by recrystallization with ether, afforded 2-PEG macromonomer as light yellow solid (4.32 g, 86\% yield). ${ }^{1} \mathrm{H}$ NMR (600 MHz, $\left.\mathrm{CDCl}_{3}, 25{ }^{\circ} \mathrm{C}\right): \delta 4.87-4.76$ (br, $1 \mathrm{H}$, $\mathrm{N}_{2} \mathrm{CH}$ ), 4.17-4.09 (dt, $2 \mathrm{H}, \mathrm{OCH}_{2}$ of chain end segment), 3.76-3.48 (m, 2H, $\mathrm{OCH}_{2}$ ), $3.37\left(\mathrm{~s}, 3 \mathrm{H}, \mathrm{CH}_{3}\right.$ of chain end segment). FT-IR $\left(\mathrm{KBr}, 25^{\circ} \mathrm{C}\right): 2962\left(v_{\mathrm{C}-\mathrm{H}}\right), 2923\left(v_{\mathrm{C}-\mathrm{H}}\right)$, $2856\left(v_{\mathrm{C}-\mathrm{H}}\right), 1643\left(v_{\mathrm{C}=\mathrm{O}}\right) \mathrm{cm}^{-1}$.

Preparation of the allylPdCl/L catalyst. ${ }^{3}$ A solution of commercially available $\pi$ allylPdCl $(3.10 \mathrm{mg}, 0.008 \mathrm{mmol})$ in THF $(1.50 \mathrm{~mL})$ was treated with the phosphine ligand (L) $(5.11 \mathrm{mg}, 0.008 \mathrm{mmol})$ at room temperature. After the resulting mixture was stirred at room temperature for $2.5 \mathrm{~h}$, it was directly used as an initiator for the polymerization of diazoacetate monomers without further purification.

Synthesis of bottlebrush polymers. ${ }^{4}$ Taking the synthesis of $\left(1-\mathrm{PS}_{30}\right)_{50}$ as an example. A solution of the as-prepared allylPdCl/L catalyst in THF $(136 \mu \mathrm{L}, 0.005$ $\mathrm{mol} / \mathrm{L}, 0.00068 \mathrm{mmol})$ was added to the solution of $1-\mathrm{PS}_{30}(100 \mathrm{mg}, 0.038 \mathrm{mmol})$ in THF $(0.4 \mathrm{~mL})$ at $25^{\circ} \mathrm{C}$. The concentrations of the macromonomer and the catalyst were $0.096 \mathrm{~mol} / \mathrm{L}$ and $0.0017 \mathrm{~mol} / \mathrm{L}$, respectively. The initial feed ratio of macromonomer to catalyst was 50/1. The reaction mixture was stirred at $25{ }^{\circ} \mathrm{C}$, and a lot of bubbles was 
released upon the addition of the allylPdCl/L catalyst. After the polymerization solution was stirred for $10 \mathrm{~h}$ at $25^{\circ} \mathrm{C}$, it was precipitated into a large amount of acetone. The volume of the polymerization solution vs acetone was 1:14. The precipitated solid was collected by centrifugation. The afforded solid was re-dissolved in THF, precipitated in acetone, and then centrifugation. After this process was repeated 3 times, the isolated solid was dried in vacuum at room temperature overnight, afforded $\left(\mathbf{1}-\mathrm{PS}_{30}\right)_{50}$ as a yellow solid (50 mg, $55 \%$ yield). SEC: $M_{\mathrm{n}}=101.0 \mathrm{kDa}, M_{\mathrm{w}} / M_{\mathrm{n}}=1.26 .{ }^{1} \mathrm{H}$ NMR $(600$ $\mathrm{MHz}, \mathrm{CDCl}_{3}, 25^{\circ} \mathrm{C}$ ): $\delta 7.37-6.32$ (brs, 5H, ArH of PS segment ), 4.17-4.09 (dt, $2 \mathrm{H}$, $\mathrm{OCH}_{2}$ of PS segment), 3.76-3.74 (t, 2H, $\mathrm{OCH}_{2}$ of PS segment), 3.52-3.31 (br, 1H, CH of main chain), 3.31-3.19 (br, $2 \mathrm{H}, \mathrm{CH}_{2} \mathrm{~S}$ of PS segment), 2.52-2.04 (m, 1H, CH of PS segment), 2.04-1.74 (m, 2H, $\mathrm{CH}_{2}$ of PS segment), 1.65-1.15 (brs, $46 \mathrm{H}, \mathrm{CH}_{2}$ and $\mathrm{CH}_{3}$ of PS segment), $0.90-0.87$ (t, $3 \mathrm{H}, \mathrm{CH}_{2} \mathrm{CH}_{3}$ of PS segment). FT-IR ( $\left.\mathrm{KBr}, 25{ }^{\circ} \mathrm{C}\right): 3067$ $\left(v_{\mathrm{Ar}-\mathrm{H}}\right), 3029\left(v_{\mathrm{Ar}-\mathrm{H}}\right), 2926\left(v_{\mathrm{C}-\mathrm{H}}\right), 2849\left(v_{\mathrm{C}-\mathrm{H}}\right), 1727\left(v_{\mathrm{C}=\mathrm{O}}\right) \mathrm{cm}^{-1}$.

Synthesis of amphiphilic bottlebrush polymer $\left.\left(1-P S_{30}\right)_{50-b-(2-P E G)}\right)_{100 .}{ }^{4} \mathrm{~A}$ solution of the as-prepared allyl $\mathrm{PdCl} / \mathrm{L}$ catalyst in $\mathrm{THF}(0.136 \mathrm{~mL}, 0.005 \mathrm{~mol} / \mathrm{L}$, $0.00068 \mathrm{mmol})$ was added to a solution of $1-\mathrm{PS}_{30}(100 \mathrm{mg}, 0.038 \mathrm{mmol})$ in THF $(0.4$ $\mathrm{mL}$ ) at $25^{\circ} \mathrm{C}$. The concentrations of macromonomer and catalyst were $0.096 \mathrm{~mol} / \mathrm{L}$ and $0.0017 \mathrm{~mol} / \mathrm{L}$, respectively. The initial feed ratio of $1-\mathrm{PS}_{30}$ to catalyst was $50 / 1$. The reaction mixture was stirred at $25{ }^{\circ} \mathrm{C}$, and a lot of bubbles was released upon the addition of the allylPdCl/L catalyst. After stirring at room temperature for 8 hours, take out a small amount of reaction solution to test GPC (SEC: $M_{\mathrm{n}}=50.0 \mathrm{kDa}, M_{\mathrm{w}} / M_{\mathrm{n}}=$ 1.15) and other analyses. Then, the 2-PEG macromonomer (154 $\mathrm{mg}, 0.076 \mathrm{mmol}$ ) was 
added, the initial feed ratio of PEG macromonomer to catalyst was 100/1, and the reaction was continued with stirring at room temperature for another 8 hours. The polymer was precipitated and isolated by centrifugation. The afforded solid was redissolved in THF, precipitated in $n$-hexane, and then subjected to centrifugation. After this process had been repeated three times, the afforded solid was dried in vacuum at room temperature overnight, obtained the amphiphilic $\left(\mathbf{1}-\mathrm{PS}_{30}\right)_{50}-b-(\mathbf{2}-\mathrm{PEG})_{100}$ as an off-white solid (128 mg, 50\% yield). SEC: $M_{\mathrm{n}}=67.0 \mathrm{kDa}, M_{\mathrm{w}} / M_{\mathrm{n}}=1.22 .{ }^{1} \mathrm{H}$ NMR (600 MHz, $\left.\mathrm{CDCl}_{3}, 25^{\circ} \mathrm{C}\right): \delta 7.23-6.34$ (br, 5H, ArH of PS segment), 4.37-4.29 (m, 2H, $\mathrm{OCH}_{2}$ of PEG segment), 4.21-4.13 (m, $2 \mathrm{H}, \mathrm{OCH}_{2}$ of PS segment), 4.11-3.49 (m, 165H, $\mathrm{OCH}_{2}$ and $\mathrm{CH}_{2}$ of PEG segment), 3.38 (s, 3H, $\mathrm{CH}_{3}$ of PEG segment), 3.28-3.25 (br, $2 \mathrm{H}, \mathrm{CH}_{2} \mathrm{~S}$ of PS segment), 3.25-3.19 (brs, $2 \mathrm{H}, \mathrm{CH}$ of main chain), 3.31-3.17 (br, $2 \mathrm{H}$, $\mathrm{CH}_{2} \mathrm{~S}$ of PS segment), 2.46-2.42 (d, $\mathrm{CH}_{2} \mathrm{~S}$ of PS segment), 2.23-2.20 (t, CH of PS segment), 2.14-1.98 (m, $\mathrm{CH}_{2}$ of PS segment), 1.96-1.02 (brs, $46 \mathrm{H}, \mathrm{CH}_{2}$ and $\mathrm{CH}_{3}$ of PS

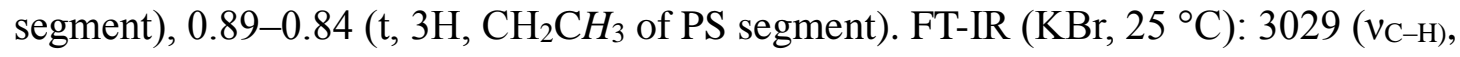
$2926\left(v_{\mathrm{C}-\mathrm{H}}\right), 2849\left(v_{\mathrm{C}-\mathrm{H}}\right), 1727\left(v_{\mathrm{C}=\mathrm{O}}\right) \mathrm{cm}^{-1}$.

Kinetic study. Taking the polymerization of $1-\mathrm{PS}_{30}$ as an example. A solution of the as-prepared allylPdCl/L catalyst in THF $(0.34 \mathrm{~mL}, 0.0042 \mathrm{~mol} / \mathrm{L}, 0.0014 \mathrm{mmol})$ was added to the mixture of macromonomer 1-PS $30(200.0 \mathrm{mg}, 0.07 \mathrm{mmol})$ and dimethyl terephthalate $(1.22 \mathrm{mg}, 0.0063 \mathrm{mmol})$ in THF $(1.00 \mathrm{~mL})$ via a syringe $\left([\mathrm{MM}]_{0}\right.$ $\left.=0.07 \mathrm{M},[\mathrm{MM}]_{0} /[\mathrm{Pd}]_{0}=50\right)$. The polymerization solution was stirred at room temperature and was followed by measuring SEC and ${ }^{1} \mathrm{H}$ NMR of the aliquots taking out from the reaction solution at appropriate time intervals. The conversion of 
macromonomer 1-PS 30 was calculated based on the peak area of unreacted 1-PS 30 relative to that of the internal standard of dimethyl terephthalate on the basis of the linear calibration curve. The $M_{\mathrm{n}}$ and $M_{\mathrm{w}} / M_{\mathrm{n}}$ of the yielded polymers were estimated by SEC and reported as equivalent to PS standards. The appearance rate constant was determined to $0.11 \mathrm{~min}^{-1}$.

AFM measurements. Stock solutions of bottlebrush polymers solutions of (1$\left.\mathrm{PS}_{30}\right)_{50},\left(\mathbf{1}-\mathrm{PS}_{30}\right)_{100},\left(\mathbf{1}-\mathrm{PS}_{30}\right)_{150}$, and $\left(\mathbf{1}-\mathrm{PS}_{30}\right)_{200}$ with the same side chains but different in the backbone DPs were prepared in dry THF $(0.001 \mathrm{mg} / \mathrm{mL})$. Samples for AFM measurements were prepared by casting $20 \mu \mathrm{L}$ aliquots of the stock solutions on monolayer mica substrate, and then the samples on mica were placed in a vacuum oven at $60{ }^{\circ} \mathrm{C}$ and dried for at least 2 hours. After cooled to room temperature, the samples were subjected to AFM measurements.

Preparation of $\left(\mathbf{1 - P S}_{30}\right)_{50-\boldsymbol{b}}-(\mathbf{2 - P E G})_{100}$ Micelles. ${ }^{5}$ Typically, a THF $(1.0 \mathrm{~mL})$ solution of (1-PS 30$)_{50}-b-(2-P E G)_{100}(16 \mathrm{mg})$ was prepared in advance. Under vigorous stirring, deionized water $(3.0 \mathrm{~mL})$ was added via a syringe pump at a flow rate of 0.05 $\mathrm{mL} / \mathrm{min}$. After addition, the dispersion was left stirring for another $12 \mathrm{~h}$. THF was then removed by dialysis (MWCO $3.5 \mathrm{kDa}$ ) against pure water for $24 \mathrm{~h}$. Fresh water was replaced approximately every $5 \mathrm{~h}$. The obtained dispersion did not exhibit any macroscopic phase separation upon standing at room temperature for more than one week, suggesting the formation of a stable micelle.

Critical micelle concentration $(C M C)$ measurement of $\left(1-P S_{30}\right)_{50-b}-(2-P E G)_{100}$ The CMC of (1-PS 30$)_{50}-b-(2-P E G)_{100}$ in aqueous solutions was measured as follows. 
The acetone solution of pyrene with the concentration of $3.0 \times 10^{-5} \mathrm{~mol} / \mathrm{L}$ was prepared and then $10 \mu \mathrm{L}$ of the solution was added into each cuvette. The acetone was allowed to evaporate. Then $2.0 \mathrm{~mL}$ of $\left(\mathbf{1}-\mathrm{PS}_{30}\right)_{50}-b-(\mathbf{2}-\mathrm{PEG})_{100}$ aqueous solutions with concentrations ranging from 0.976 to $500 \mathrm{mg} / \mathrm{L}$ were added into the pyrene-containing cuvette separately. Upon sonication for $10 \mathrm{~min}$, the solutions were kept at room temperature and equilibrated for $24 \mathrm{~h}$ before fluorescent emission measurements with an excitation wavelength of $335 \mathrm{~nm}$. For each spectrum obtained, the intensity ratio of the emission intensity at 373 to $393 \mathrm{~nm}, I_{1} / I_{3}$, was calculated. The CMC was estimated as the concentration at which $I_{1} / I_{3}$ began to drop, indicating that polymer aggregation occurred.

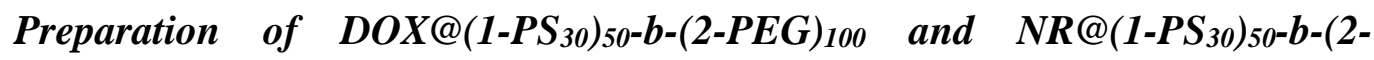
$\boldsymbol{P E G})_{100 .}{ }^{5}\left(\text { 1-PS }_{30}\right)_{50}-b-(2-P E G)_{100}(15.00 \mathrm{mg})$ and DOX (10.00 mg) were dissolved in THF $(1.50 \mathrm{~mL})$ at $25^{\circ} \mathrm{C}$ under stirring, then the deionized water $(3.50 \mathrm{~mL})$ was slowly added to the solution using a syringe pump within $2 \mathrm{~h}$. After that the dispersion was allowed to stir for another $12 \mathrm{~h}$. The THF and unloaded DOX were removed by dialysis (MWCO $3.5 \mathrm{kDa}$ ) against pure water for $24 \mathrm{~h}$. Fresh water was replaced approximately every $5 \mathrm{~h}$. The loading content for DOX was calculated based on the emission spectrum of $\operatorname{DOX}\left(\lambda_{\mathrm{ex}}=480 \mathrm{~nm}\right)$ against a standard calibration curve. Loading content $(\%)=$ (weight of molecules) / (weight of molecules + weight of polymer) $\times 100 \%$.

Following the same procedure, NR@(1-PS 30$)_{50}-b-(2-P E G){ }_{100}$ was also prepared.

In vitro DOX release profile. Taking $\mathrm{DOX} @(1-\mathrm{PS} 30)_{50}-b-(2-\mathrm{PEG})_{100}$ as an example. The DOX@(1-PS 30$)_{50}-b-(2-P E G)_{100}(0.50 \mathrm{~g} / \mathrm{L}, 1 \mathrm{~mL})$ was dispersed in 
deionized water and transferred to a dialysis tube (MWCO $3.5 \mathrm{kDa}$ ) immersed in 300 $\mathrm{mL}$ deionized water media at $37^{\circ} \mathrm{C}$. The volume of polymer solution vs. deionized water was $1: 300$. Aliquots $(4 \mathrm{~mL})$ of the external medium were withdrawn at selected time intervals, and replaced with the same volume of fresh deionized water, the concentration of DOX was calculated based on the emission spectra of DOX $\left(\lambda_{\mathrm{ex}}=480\right.$ $\mathrm{nm})$ against a standard calibration curve. The cumulative amount of released drug was calculated and the percentages of drug release from DOX@(1-PS 30$)_{50}-b-(2-P E G)_{100}$ were plotted against time.

Cytotoxicity investigation. ${ }^{6}$ Cell viability was examined by the MTT assay. HeLa cells $\left(5 \times 10^{3}\right.$ cells/well; $\sim 100 \mathrm{~K}$ per $\left.\mathrm{mL}\right)$ in Dulbecco's modified Eagle's medium (DMEM) complete medium were plated into a 96-well plate and incubated overnight. HeLa cells were then exposed to $\left(\mathbf{1}-\mathrm{PS}_{30}\right)_{50}-b-(\mathbf{2}-\mathrm{PEG})_{100}, \mathrm{DOX} @\left(\mathbf{1}-\mathrm{PS}_{30}\right)_{50}-b-(\mathbf{2}-$ PEG) 100 and free DOX at $37{ }^{\circ} \mathrm{C}$ in DMEM complete medium with varying polymer concentrations. After incubation for $48 \mathrm{~h}$, cells were rinsed with PBS buffer and DMEM complete medium. Cell injury was directly observed by calcein-AM and propidium idodide (PI) staining for $20 \mathrm{~min}$. The live cells were stained with calcein-AM and dead cells were stained with PI. Cells incubated with PBS only were served as positive control. 
Table S1. Characterization Data for 1-PS ${ }_{\mathrm{n}}{ }^{a}$

\begin{tabular}{ccccccc}
\hline run & polymers & $\mathrm{St} /[\mathrm{cat} .]_{0}^{b}$ & $M_{\mathrm{n}}{ }^{c}(\mathrm{kDa})$ & $M_{\mathrm{w}} / M_{\mathrm{n}}{ }^{c}$ & Conversion $^{d}$ & Yield $^{e}$ \\
\hline 1 & $\mathbf{1}_{\mathrm{PS}} \mathrm{PS}_{20}$ & 20 & 2.3 & 1.02 & $82 \%$ & $78 \%$ \\
2 & $\mathbf{1}_{\mathrm{PS}} \mathrm{PS}_{30}$ & 30 & 2.8 & 1.04 & $84 \%$ & $72 \%$ \\
3 & 1-PS $_{40}$ & 40 & 3.6 & 1.03 & $83 \%$ & $72 \%$ \\
\hline
\end{tabular}

${ }^{a}$ The polymers were synthesized according to Scheme $1 \mathrm{~A}$ in main text. ${ }^{b}$ The initial feed ratio the of St monomer to the RAFT catalyst (cat.). ${ }^{c}$ The $M_{\mathrm{n}}$ and $M_{\mathrm{w}} / M_{\mathrm{n}}$ were determined by SEC. ${ }^{d}$ Monomer conversion measured by ${ }^{1} \mathrm{H}$ NMR. ${ }^{e}$ Isolated yield.

Table S2. Characterization Data for the Bottlebrush Polymers. ${ }^{a}$

\begin{tabular}{ccccccc}
\hline run & polymers & {$[\mathrm{MM}]_{0} /[\mathrm{Pd}(\mathrm{II})]_{0}{ }^{b}$} & $M_{\mathrm{n}}{ }^{c}(\mathrm{kDa})$ & $M_{\mathrm{w}} / M_{\mathrm{n}}{ }^{c}$ & Conversion $^{d}$ & Yield $^{e}$ \\
\hline 1 & $\left(\mathbf{1}-\mathrm{PS}_{30}\right)_{30}$ & 30 & 60.0 & 1.26 & $72 \%$ & $59 \%$ \\
2 & $\left(\mathbf{1}-\mathrm{PS}_{30}\right)_{50}$ & 50 & 101.0 & 1.26 & $72 \%$ & $55 \%$ \\
3 & $\left(\mathbf{1}-\mathrm{PS}_{30}\right)_{100}$ & 100 & 198.0 & 1.13 & $71 \%$ & $50 \%$ \\
4 & $\left(\mathbf{1}-\mathrm{PS}_{30}\right)_{150}$ & 150 & 258.0 & 1.12 & $65 \%$ & $45 \%$ \\
5 & $\left(\mathbf{1}-\mathrm{PS}_{30}\right)_{200}$ & 200 & 301.0 & 1.16 & $62 \%$ & $42 \%$ \\
\hline
\end{tabular}

${ }^{a}$ The polymers were synthesized according to Scheme $1 \mathrm{~A}$ in main text. ${ }^{b}$ The initial feed ratio the of 1-PS $30(\mathrm{MM})$ to the $\mathrm{Pd}(\mathrm{II})$ catalyst. ${ }^{c}$ The $M_{\mathrm{n}}$ and $M_{\mathrm{w}} / M_{\mathrm{n}}$ were determined by SEC. ${ }^{d}$ Macromonomer conversions were measured by ${ }^{1} \mathrm{H}$ NMR. ${ }^{e}$ Isolated yield.

Table S3. DLS Results for $\left(1-\mathrm{PS}_{30}\right)_{50}-b-(2-\mathrm{PEG})_{100}$.

\begin{tabular}{cccc}
\hline run & samples & size $(\mathrm{nm})$ & PDI \\
\hline 1 & $\left(\mathbf{1}-\mathrm{PS}_{30}\right)_{50}-b-(\mathbf{2}-\mathrm{PEG})_{100}(\mathrm{THF})^{a}$ & $\sim 6$ & 0.095 \\
2 & $\left(\mathbf{1}-\mathrm{PS}_{30}\right)_{50}-b-(\mathbf{2}-\mathrm{PEG})_{100}\left(\mathrm{H}_{2} \mathrm{O}\right)^{b}$ & $\sim 146$ & 0.100 \\
3 & ${\text { DOX } @\left(\mathbf{1}-\mathrm{PS}_{30}\right)_{50}-b-(\mathbf{2}-\mathrm{PEG})_{100}\left(\mathrm{H}_{2} \mathrm{O}\right)^{b}}$ & $\sim 190$ & 0.129 \\
\hline
\end{tabular}

${ }^{a}$ Measured in THF at $25^{\circ} \mathrm{C}(c=0.4 \mathrm{mg} / \mathrm{mL}) .{ }^{b}$ Measured in $\mathrm{H}_{2} \mathrm{O}$ at $25^{\circ} \mathrm{C}(c=1 \mathrm{mg} / \mathrm{mL})$. 


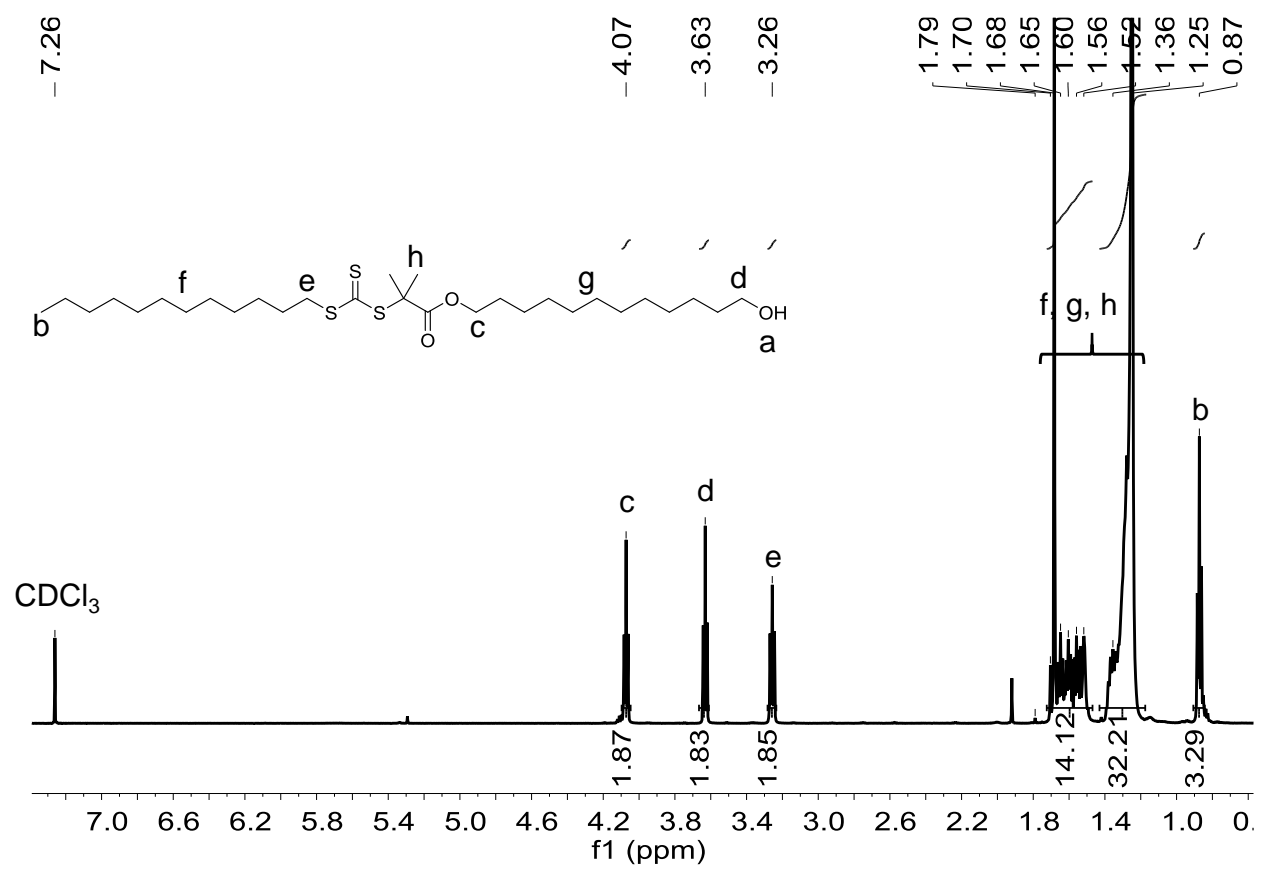

Figure S1. ${ }^{1} \mathrm{H}$ NMR $(600 \mathrm{MHz})$ spectrum of compound 1 measured in $\mathrm{CDCl}_{3}$ at $25{ }^{\circ} \mathrm{C}$.

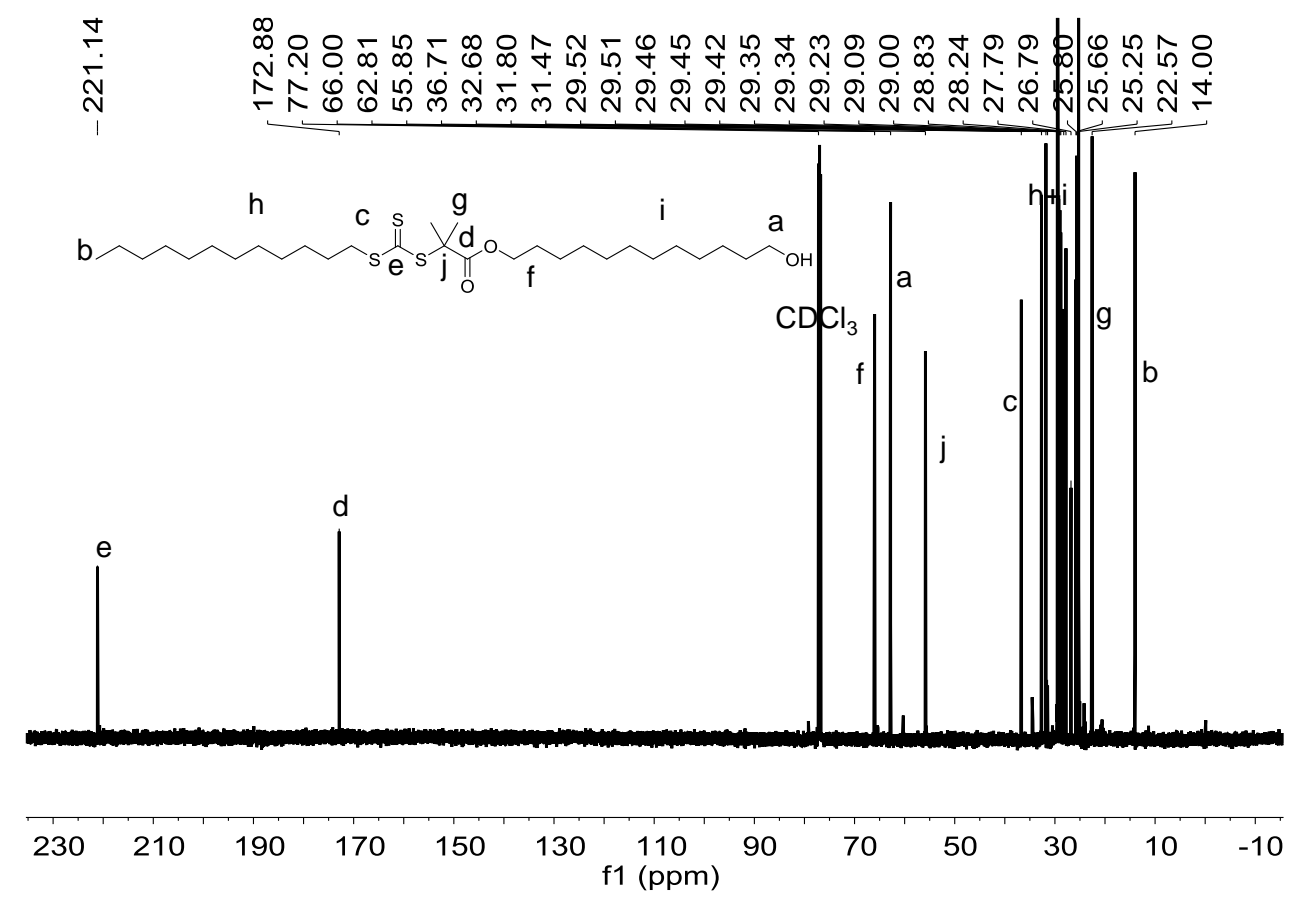

Figure S2. ${ }^{13} \mathrm{C}$ NMR $(150 \mathrm{MHz})$ spectrum of compound 1 measured in $\mathrm{CDCl}_{3}$ at $25{ }^{\circ} \mathrm{C}$. 


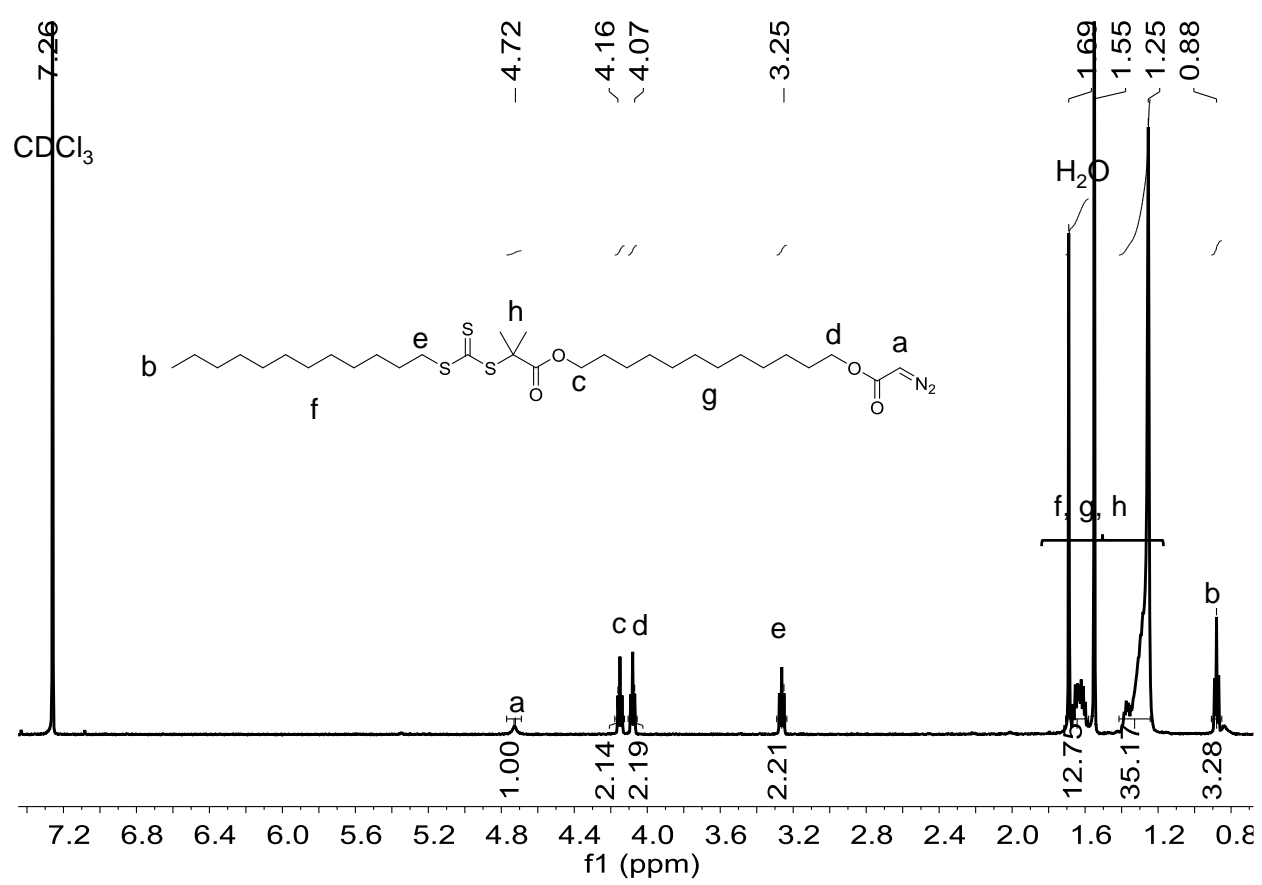

Figure S3. ${ }^{1} \mathrm{H}$ NMR $(600 \mathrm{MHz})$ spectrum of compound 3 measured in $\mathrm{CDCl}_{3}$ at $25{ }^{\circ} \mathrm{C}$.

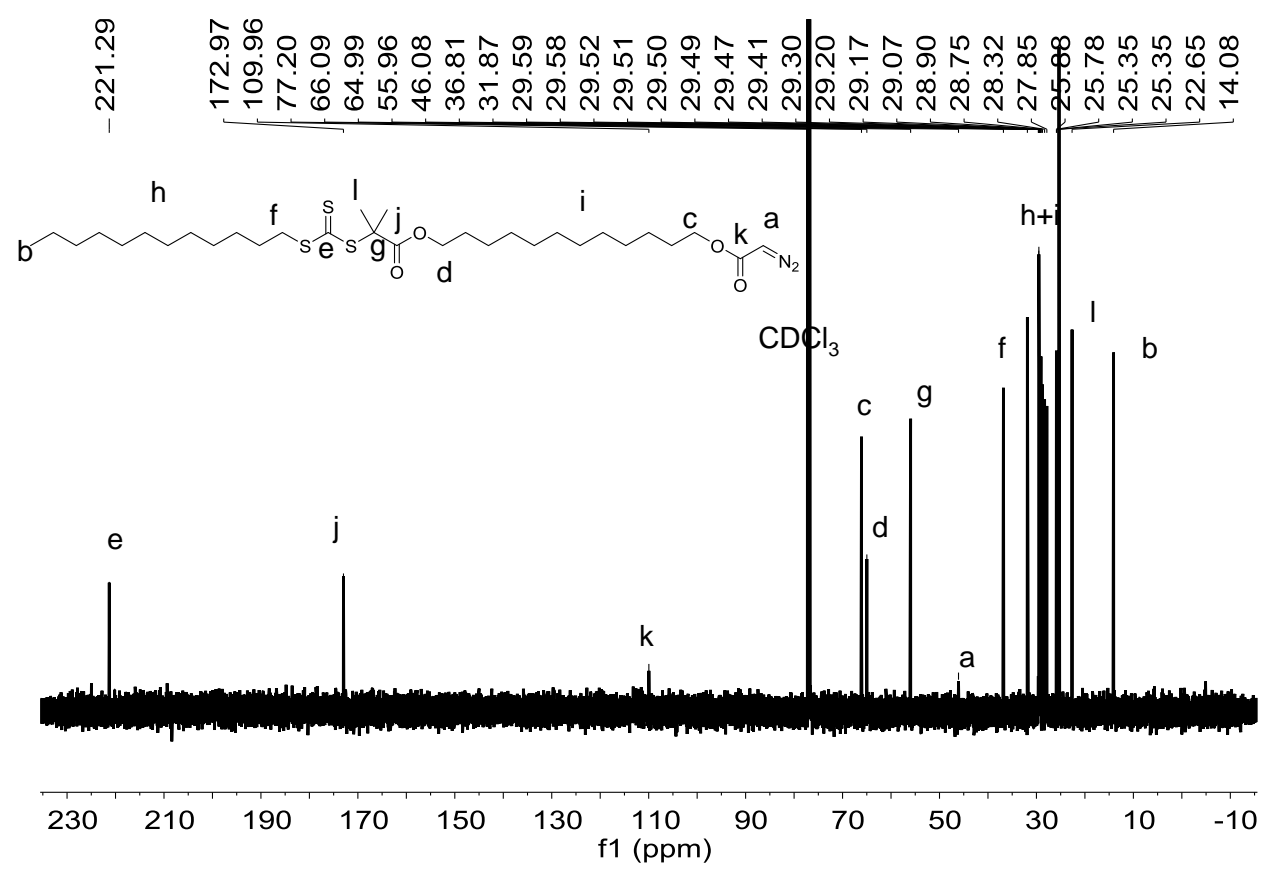

Figure S4. ${ }^{13} \mathrm{C}$ NMR $(150 \mathrm{MHz})$ spectrum of compound 3 measured in $\mathrm{CDCl}_{3}$ at $25{ }^{\circ} \mathrm{C}$. 


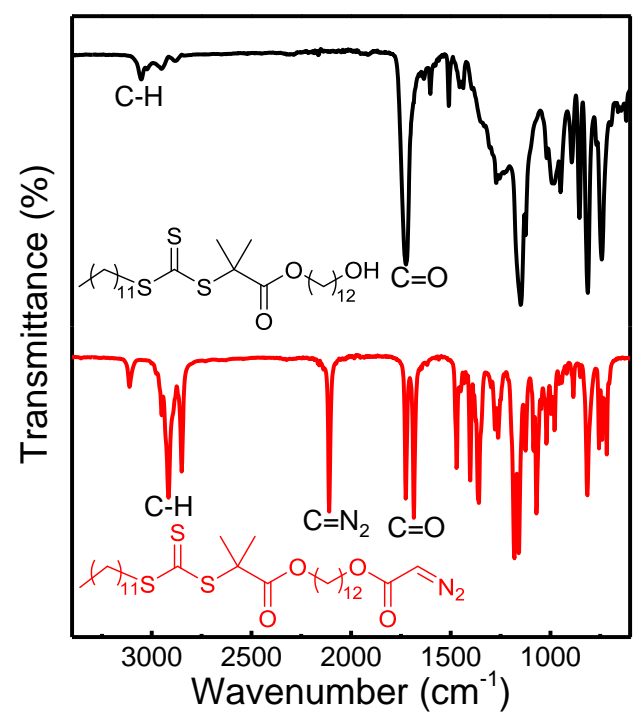

Figure S5. FT-IR spectra of compound $\mathbf{1}$ and compound $\mathbf{3}$ measured at $25{ }^{\circ} \mathrm{C}$ using $\mathrm{KBr}$ pellets.
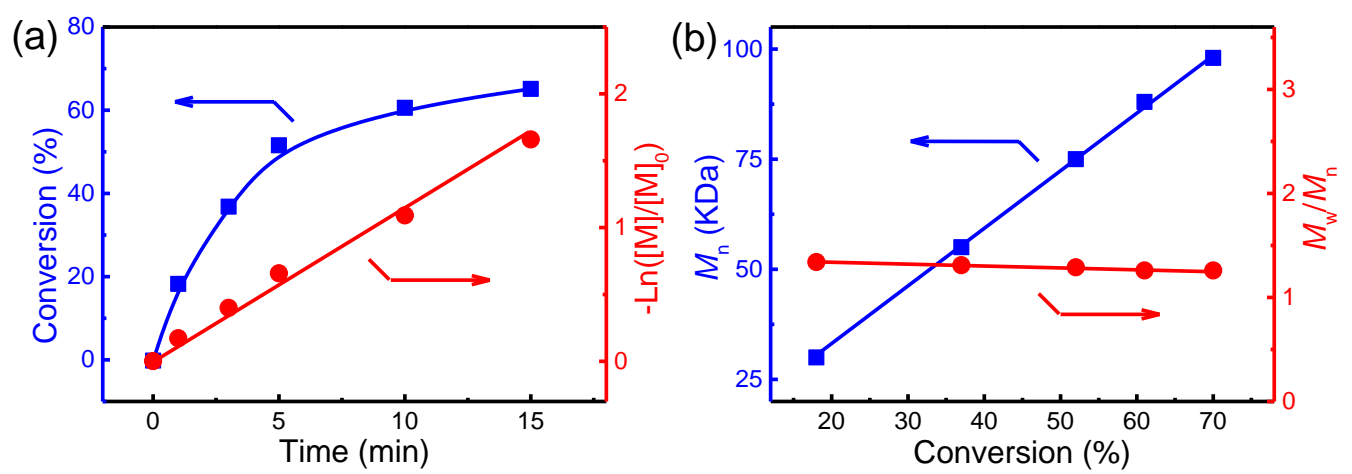

Figure S6. (a) Plot of 1-PS 30 conversion as a function of the polymerization time and first-order kinetic plot for the polymerization initiated by the $\mathrm{Pd}(\mathrm{II}) / \mathrm{L}$ catalyst. (b) Plots of $M_{\mathrm{n}}$ and $M_{\mathrm{w}} / M_{\mathrm{n}}$ values as a function of the conversion of $1-\mathrm{PS}_{30}$ catalyzed by $\mathrm{Pd}(\mathrm{II}) / \mathrm{L}$ in $\mathrm{THF}$ at $25^{\circ} \mathrm{C}\left(\left[1-\mathrm{PS}_{30}\right] 0 /[\mathrm{Pd}(\mathrm{II})]_{0}=50\right)$. 


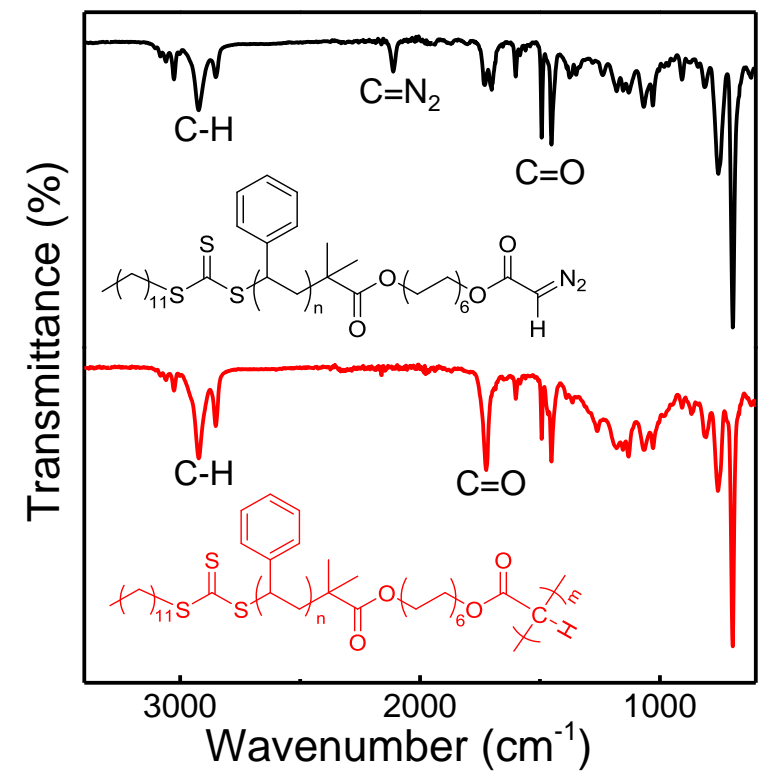

Figure S7. FT-IR spectra of 1-PS 30 and (1-PS $\left.{ }_{30}\right)_{30}$ measured at $25^{\circ} \mathrm{C}$ using $\mathrm{KBr}$ pellets.

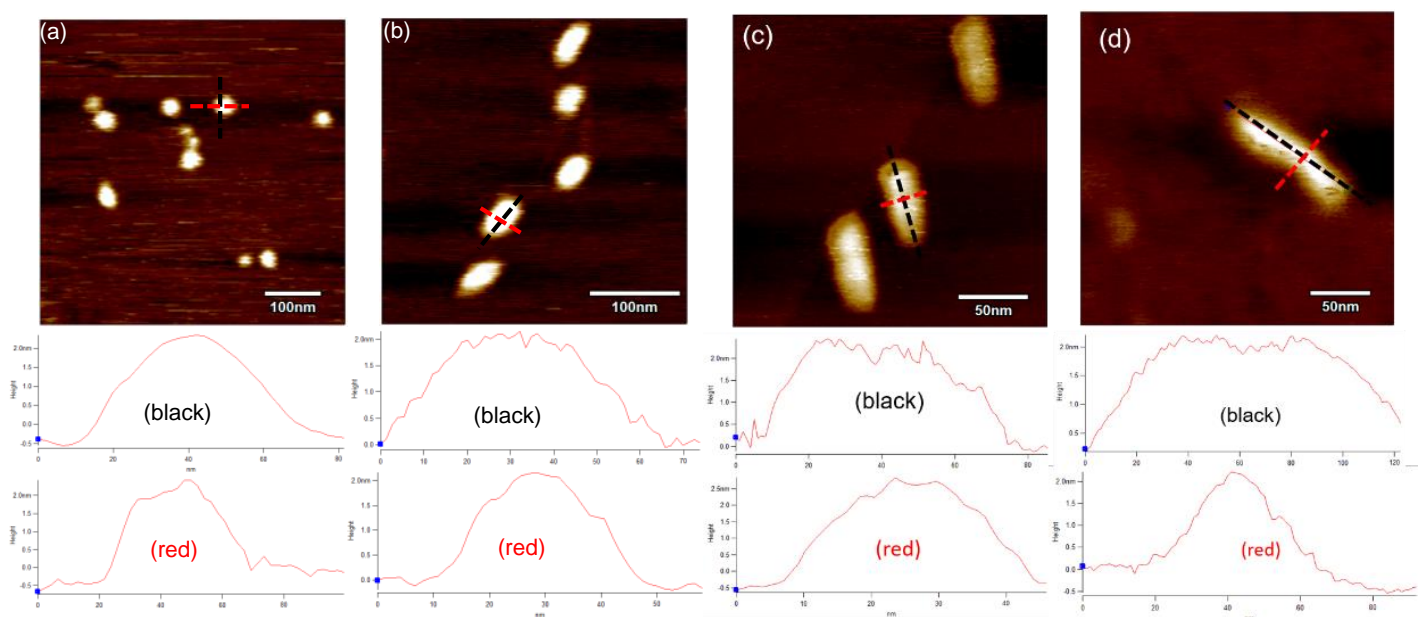

Figure S8. AFM height images and the corresponding height cross-section analysis of $\left(\mathbf{1}^{-} \mathrm{PS}_{30}\right)_{50}(\mathrm{a}),\left(\mathbf{1}_{-}-\mathrm{PS}_{30}\right)_{100}(\mathrm{~b}),\left(\mathbf{1}-\mathrm{PS}_{30}\right)_{150}(\mathrm{c})$, and $\left(\mathbf{1}-\mathrm{PS}_{30}\right)_{200}(\mathrm{~d})$ casted from THF solutions on mica. 


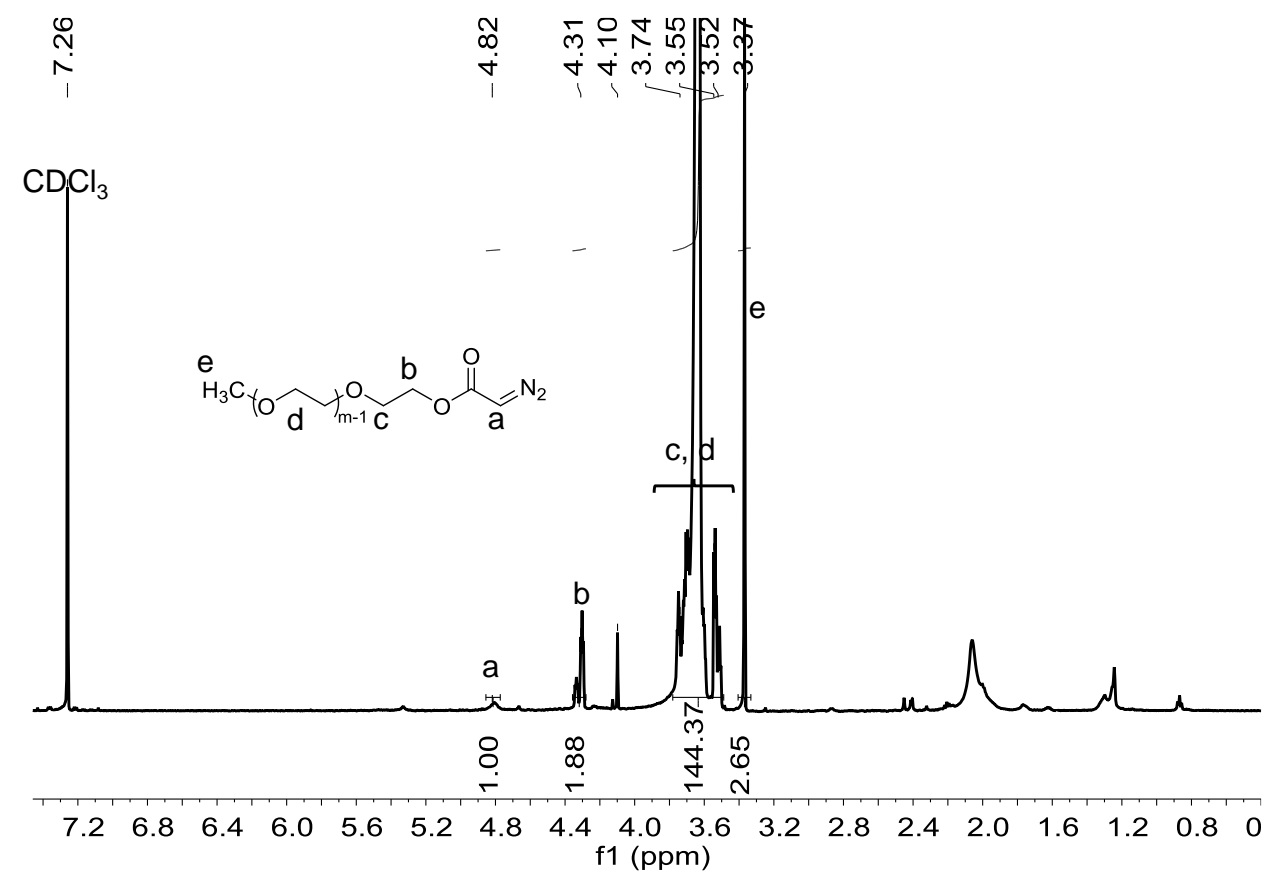

Figure S9. ${ }^{1} \mathrm{H}$ NMR $(600 \mathrm{MHz})$ spectrum of 2-PEG measured in $\mathrm{CDCl}_{3}$ at $25{ }^{\circ} \mathrm{C}$.

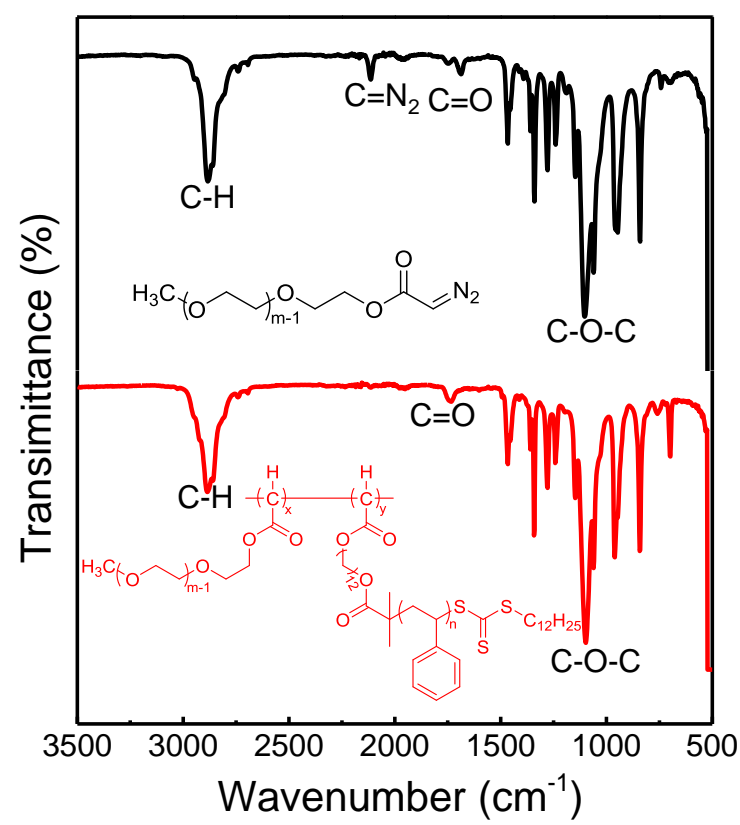

Figure S10. FT-IR spectra of 2-PEG and $\left(1-\mathrm{PS}_{30}\right)_{50}-b-(2-\mathrm{PEG})_{100}$ measured at $25{ }^{\circ} \mathrm{C}$ using $\mathrm{KBr}$ pellets. 


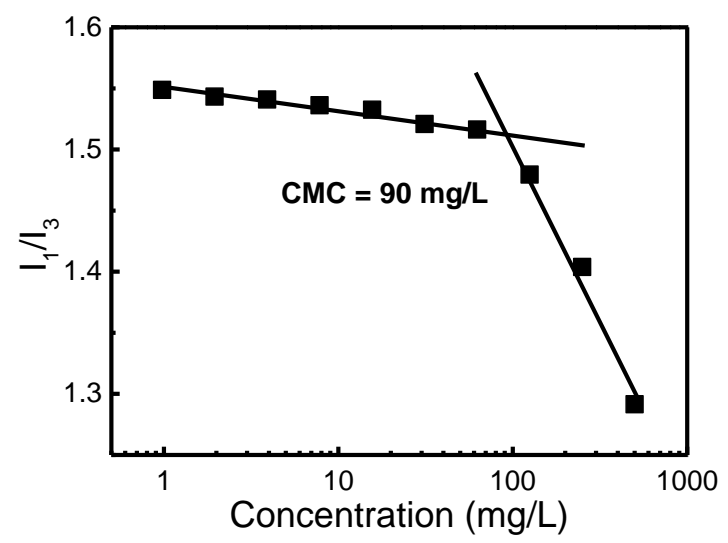

Figure S11. Plot of $\mathrm{I}_{1} / \mathrm{I}_{3}$ versus the concentration of $\left(\mathbf{1}-\mathrm{PS}_{30}\right)_{50}-b-(2-\mathrm{PEG})_{100}$ in water.

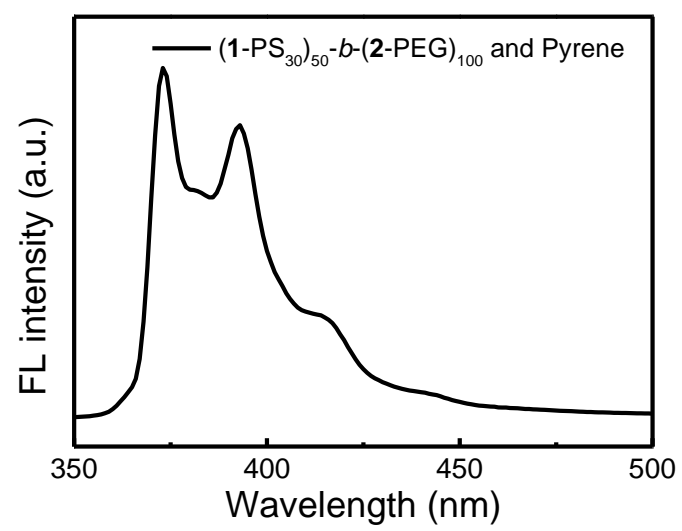

Figure S12. Fluorescent spectrum of pyrene and (1-PS 30$)_{50}-b-(2-P E G)_{100}$ in water at $25^{\circ} \mathrm{C}$
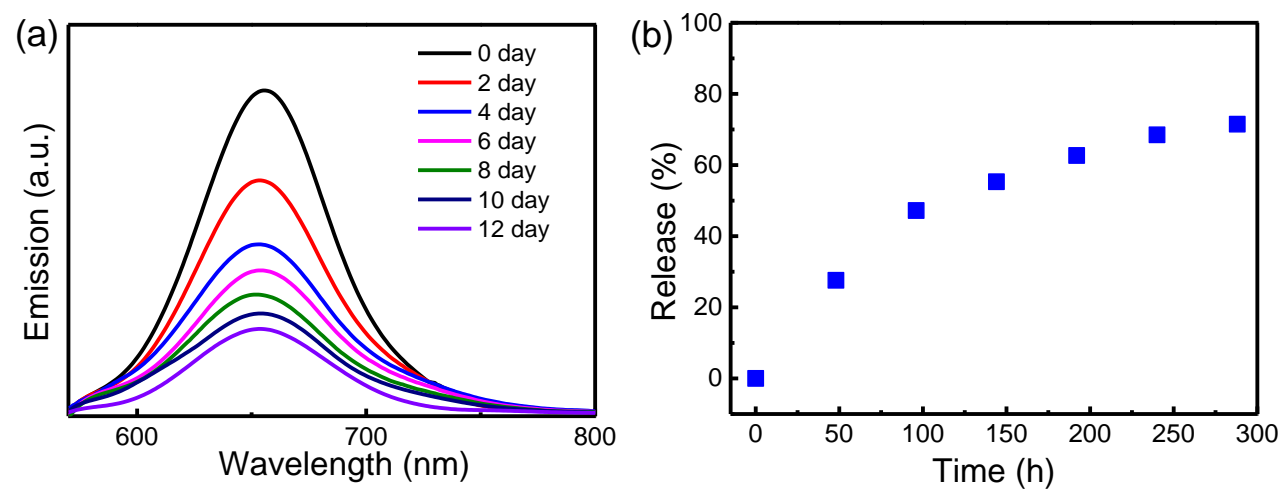

Figure S13. (a) Fluorescent spectra of NR@(1-PS 30$)_{50}-b-(2-P E G)_{100}$ in deionized water.

(b) Time-dependent NR release for NR@ $\left(\mathbf{1}-\mathrm{PS}_{30}\right)_{50}-b-(\mathbf{2}-\mathrm{PEG})_{100}$ in deionized water. 


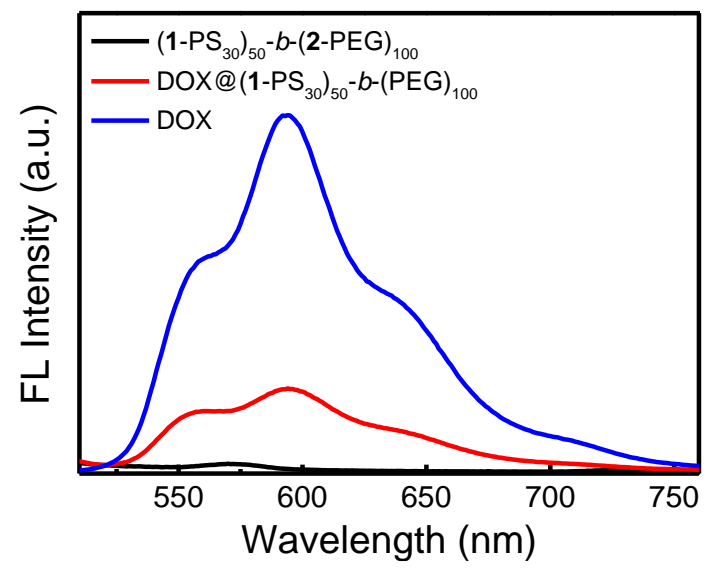

Figure S14. Fluorescent spectra of $\left(1-\mathrm{PS}_{30}\right)_{50}-b-(2-\mathrm{PEG})_{100}, \mathrm{DOX} @\left(1-\mathrm{PS}_{30}\right)_{50}-b-(2-$ PEG) $)_{100}$, and DOX measured in $\mathrm{H}_{2} \mathrm{O}$ at $25{ }^{\circ} \mathrm{C}$. 


\section{References}

(1) Chiefari, J.; Mayadunne, R. T. A.; Moad, C. L.; Moad, G.; Rizzardo, E.; Postma,

A.; Thang, S. H. Thiocarbonylthio Compounds $(\mathrm{SC}(\mathrm{Z}) \mathrm{S}-\mathrm{R})$ in Free Radical Polymerization with Reversible Addition-Fragmentation Chain Transfer (RAFT Polymerization). Effect of the Activating Group Z. Macromolecules 2003, 36, 22732283.

(2) Toma, T.; Shimokawa J.; Fukuyama T. N,N'-Ditosylhydrazine: A Convenient Reagent for Facile Synthesis of Diazoacetates. Org. Lett. 2007, 9, 3195-3197.

(3) Chu, J.-H.; Xu, X.-H.; Kang, S.-M.; Liu, N.; Wu, Z.-Q. Fast Living Polymerization and Helix-Sense-Selective Polymerization of Diazoacetates Using Air-Stable Palladium(II) Catalysts. J. Am. Chem. Soc. 2018, 140, 17773-17781.

(4) Li, N.-N.; Li, X.-L.; Xu, L.; Liu, N.; Wu, Z.-Q. Highly Enantioselective and HelixSense-Controlled Synthesis of Stereoregular Helical Polycarbenes Using Chiral Palladium(II) Catalysts. Macromolecules 2019, 52, 7260-7266.

(5) Han, X.; Zhang, J.; Qiao, C.-Y.; Zhang, W.-M.; Yin, J.; Wu, Z.-Q. High-Efficiency Cell-Penetrating Helical Poly(phenyl isocyanide) Chains Modified Cellular Tracer and Nanovectors with Thiol Ratiometric Fluorescence Imaging Performance. Macromolecules 2017, 50, 4114-4125.

(6) Liu, W.-B.; Xu, X.-H.; Kang, S.-M.; Song, X.; Zhou, L.; Liu, N.; Wu, Z.-Q. Bottlebrush Polymers Carrying Side Chains on Every Backbone Atom: Controlled Synthesis, Polymerization-Induced Emission, and Circularly Polarized Luminescence. Macromolecules 2021, 54, 3158-3168. 